\title{
Assessment of Open Grown Trees Composition and Diversity in Selected Research Institutes in Peri-Urban Ibadan, Oyo state, Nigeria
}

\section{${ }^{1}$ OLAJIIRE-AJAYI, BL; ${ }^{2}$ IBODE, RT; ${ }^{2}$ TUNDE-FRANCIS, AA; ${ }^{1}$ OKELEKE, SO}

\author{
${ }^{*}$ Forestry Technology Department, Federal College of Forestry, Ibadan, Nigeria \\ Forestry Research Institute of Nigeria, P.M.B 5087, Jericho, Ibadan, Nigeria \\ ${ }^{2}$ Department of Basic and General Science, Federal College of Forestry, Ibadan \\ *Corresponding Author Email: jiirebolanle@gmail.com
}

\begin{abstract}
Urban green spaces are rapidly deteriorating in most parts of Nigeria. The study assessed open grown trees composition and diversity in selected Research Institutes within Ibadan Region with the aim of comparing the ecological diversity in the study locations. This was achieved through species identification and mensuration of all open grown trees species that were accessible in the study areas. Open grown trees with Diameter at breast height $\geq 10 \mathrm{~cm}$ were assessed for growth characteristics of total height and diameter at breast height. Basal area and volume were estimated from measured growth characteristics. Tree species were identified by a taxonomist at Federal Herbarium in Ibadan. Biodiversity indices of Shannon diversity index, species evenness and species dominance were computed to see variation in tree community of the areas. The Shannon diversity index calculated was higher in IITA with a value of 3.04 compared to that of CRIN with a value of 2.36. A dominance value of 0.15 and 0.05 was obtained for CRIN and IITA respectively. The study concludes that both institutes are repository of large diversity of tree species thereby, helping in the conservation of biodiversity while ameliorating weather. It is recommended that educational institutions from all levels located within the region as well as private organizations and individuals should plant trees within their domains in order to create conducive green environments that would promote sustainable environment in the region. This is possible when government provide adequate incentive and annual rewards for establishments with the best green environments.
\end{abstract}

\section{DOI: https://dx.doi.org/10.4314/jasem.v25i7.23}

Copyright: Copyright $(92021$ Olajiire-Ajayi et al. This is an open access article distributed under the Creative Commons Attribution License (CCL), which permits unrestricted use, distribution, and reproduction in any medium, provided the original work is properly cited.

Dates: Received: 10 May 2021; Revised: 28 June 2021; Accepted: 01 July 2021

Keywords: Open Grown Trees, Conservation, Species Diversity, Urban Green

Trees are one of the most important components of urban green space and they play an important role in street aesthetics. As an integral component of urban green infrastructure, tree, especially trees selection is crucial to successfully shaping a better urban environment (Adeyemi and Adesoye, 2016). An opengrown tree is a tree that has grown virtually all its life without competition from other trees. It usually has a short, squalls fat trunk with a very large diameter, spreading limbs of which some grow out almost horizontally. They generally have a large dome-like crown compared with a forest from trees that is tall with a narrow trunk and a small crown (Browne, 2001). The importance and conservation of the open grown tree as a natural, cultural and literacy icons is now gaining recognition across the world (Nowak et al., 2007). Trees in urban and Semi- urban areas provide numerous benefits such as public aesthetic appeal, the root of trees preventing erosion, tree covers and branches improving air quality as well as serving as wind break. Trees also serve as shelterbelts in dry lands, protect water flow, sequestrate carbon, ameliorate harsh weather condition, as raw materials to the wooden industries, preserve water shed, serve as recreation centers for relaxation parks and garden. It also provides security for poor urban people through the provision of edible vegetable, fruits, nuts, planting of low care fruit bearing trees, etc. (Onyekwelu et al., 2008).Urban forest provides numerous tangible environmental benefits that often go unrecognized as reported by (McPherson and Simpson, 1999). Early this century, there has been increased research on quantification of ecosystem services, the direct benefits that urban forest ecosystem provides to people (Millennium Ecosystem assessment, 2005). Urban trees are increasingly being fell due to anthropogenic activities and its attendant urban growth and thus, the disappearance and threatening of tree species (Babalola and Raji, 2016). Statistics show that urban green spaces are rapidly deteriorating in most part of Nigeria and little attention is given to their composition and diversity. Studies on grown 
characteristics and diversity of semi-urban green spaces have also not considered research institutes and spaces surrounding them.

Research and enumeration of urban forest composition and diversity can help create awareness of what is in an urban forest within an area. This helps to provide a basis for management of such tress resource. This can further help to know factors that influence urban environment ecology and how this can be managed properly during constructions within the built-up environment. Assessing the status and trends of tree species diversity population is essential for sustainable development, strategies and planning of urban centers in Nigeria (Adekunle et al., 2013).

Therefore, the objective of this paper is to assess open grown trees composition and diversity in selected Research Institutes in Peri-Urban Ibadan, Oyo state, Nigeria.

\section{MATERIALS AND METHODS}

Study Area: The study was conducted in Ibadan Region and specifically at the two research institutes located towards the Southern and Northern parts of the Region. The two Research Institutes are the Cocoa Research Institute of Nigeria (CRIN) and International
Institute of Tropical Agriculture (IITA). Cocoa Research Institute of Nigeria (CRIN), Ibadan at IdiAyunre in Oluyole Local Government of Oyo State. It is lies on latitude $03^{\circ} 50^{\prime}$ 'East of the Greenwich Meridian and longitude $07^{\circ} 20^{\prime \prime}$ North of the Equator lying on an altitude 122 meter above sea level (Ajewole and Iyanda, 2010). The area is characterized by wet season of about 6 months and a pronounced dry season of another 6 months. The mean annual rainfall may reach about $1200 \mathrm{~mm}$. Annual mean temperature is about $25^{\circ} \mathrm{C}$ with high relative humidity of about $76 \%$ (Ajewole and Iyanda, 2010). International Institute of Tropical Agriculture (IITA) is located along old Oyo road in the Akinyele Local Government Area, Moniya, Ibadan, Oyo State. It lies on Longitude $07^{\circ} 30^{\prime} 8^{\prime \prime} \mathrm{N}$ and latitude $03^{\circ} 54^{\prime} 37^{\prime \prime} \mathrm{E}$ and altitude 243 meter above sea level (Tenkouano and Baiyeri, 2007). The area is characterized by two distinct seasons; the wet season which lasts for about 8 months and the dry season which is for about 4 months. Rainfall pattern is bimodal, with mean annual rainfall range of 1300$1500 \mathrm{~mm}$ most of which fall between May and September. The Average daily temperature ranges between $21^{\circ} \mathrm{Cand} 23^{\circ} \mathrm{C}$ while the maximum is between $28^{\circ} \mathrm{C}$ and $34^{\circ} \mathrm{C}$. The average relative humidity range is to $64 \%$ to $83 \%$ (Tenkouano and Baiyeri, 2007).

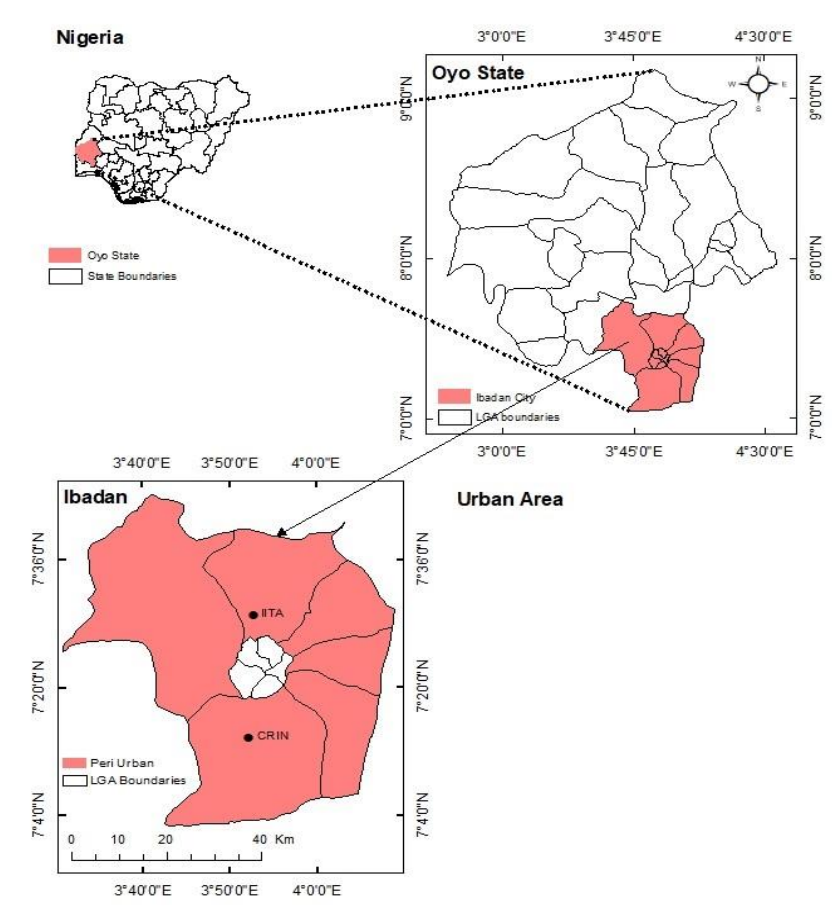

Fig 1: Map of study area

Data Collection: Growth variables such as total height (m) and diameter at breast height (dbh) were measured. Basal area and volume were estimated from measured growth characteristics of height and basal area. The species were identified by a taxonomist from the Federal Herbarium, Ibadan. 
Data from the quantitative measurements were subjected to ecological analysis using indices such as relative dominance, species diversity and evenness.

Measurement of Growth Variable: Total Height: This is the distance between the ground level and the apex of the tree species. It was obtained by taking the reading at the top (RT) and reading at the base (RB) which is usually negative and positive. It was measured with the Spiegel Relaskope.

Diameter at Breast Height $(D B H)$ : The Diameter at breast height is the measurement of a point on the standing tree which is $1.30 \mathrm{~m}$ above the ground level. The tree parameter was taken for trees species within the temporary sample plots. It was measured with the support of diameter tape (Valladares and Niinemets, 2008).

\section{Estimations Used}

Basal Area: Basal area is used to describe the average amount of an area occupied by the tree stems. It is defined as the total cross-sectional area of all stems in a stand measured at breast height. It was calculated using the formula

$$
B A=\frac{D^{2}}{4}
$$

Where: $\mathrm{BA}=$ basal Area; $\mathrm{D}=$ Diameter at Breast Height; $\pi=3.14$

Volume: The volume of trees in the study areas were estimated using the Newton's formula (Hush et al., 2003). The formula is given by:

$$
V=B A \times H
$$

Where: $\mathrm{BA}=$ basal Area; $\mathrm{H}=$ Height

Ecological Analyses: The number of qualitative and quantitative indices of species diversity have been proposed by several workers (Simpson, 1949; Margalef, 1972; Shannon and Wiener, 1963; Pielou, 1975; Whittaker,1972) which provided information on compositional change at different analytical levels that include species diversity in relation to size of area, relationship between local and regional species diversity and diversity along gradient across space or environmental factors(Busing and White,1997; Gaston, 2000).

Information on floristic composition, diversity is absolutely essential in understanding the forest ecosystem dynamic (Gentry, 1990). The following analyses were carried out for all the enumerated trees;
Species Diversity Index: Species diversity index was computed using the Shannon-Wiener diversity index after Kent and Coker (1992).

$$
\mathrm{H}=\sum_{i=1}^{S} P i \ln (P i)
$$

Where: $\mathrm{H}^{\prime}$ = Shannon-Wiener diversity index; $\mathrm{s}=$ total number of species in the study area; $\mathrm{P}_{\mathrm{i}}=$ proportion of 's' made up of the $i^{\text {th }}$ species; $\int \mathrm{n}=$ natural logarithm.

Species Relative Dominance: Species relative dominance (RD) usually in percentage (\%) was used in assessing relative space occupancy. It was estimated using after (Aidar et al., 2001).

$$
R D=\sum B a i / B a n \times 100
$$

Where: $\mathrm{B} a i=$ basal area of all trees belonging to a particular species I; Ban = basal area of all trees in a city.

\section{RESULTS AND DISCUSSION}

Floristic Composition and Structure of Tree Species: A total of 166 trees belonging to different species and families were identified and enumerated in the two study locations (CRIN and IITA). Fabaceae had the highest individuals of 52 among the identified and enumerated trees species. This was closely followed by the Annonaceae having 29 individuals in CRIN study only site (Table 1).

Species and family of trees encountered in study sites: 114 individuals' trees of 20 species belonging to 12 families were identified and enumerated in CRIN. Annonaceace family had the highest individual of 29.

This was followed by the Fabaceae family with 27 individuals. Next to the Family is the Combretaceae family with 12 individuals. Burnham and Johnson (2004) reported that Fabaceae is the most commonly reported family in Tropical Rain Forest and even in dry forest in Africa.

This is because of its invasiveness that aids in its spread (Table 2a).: 52 individual's trees of 24 species belonging to 8 families were identified and enumerated.

The number of individuals in each family were almost evenly spread as number of individuals in each family range from 1-5 with the highest being 5 individuals. This implies that no individual species dominant in IITA as all identified species are almost equally spread board. Most of them had individuals from between 1 and 2 (Table 2b). 
Table 1: Floristic Composition and Structure of Tree Species

\begin{tabular}{llll}
\hline Family & Frequency & CRIN & IITA \\
\hline Anacardeacea & $\mathbf{6}$ & $\mathbf{1}$ & $\mathbf{5}$ \\
Arecaceae & $\mathbf{3}$ & $\mathbf{3}$ & - \\
Annonaceace & $\mathbf{2 9}$ & $\mathbf{2 9}$ & - \\
Bignoniaceace & $\mathbf{1}$ & $\mathbf{1}$ & - \\
Combretaceae & $\mathbf{1 8}$ & $\mathbf{1 2}$ & $\mathbf{6}$ \\
Dipterocarpaceae & $\mathbf{2}$ & $\mathbf{2}$ & - \\
Fabaceae & $\mathbf{5 2}$ & $\mathbf{3 7}$ & $\mathbf{1 5}$ \\
Malvaceae & $\mathbf{2 4}$ & $\mathbf{1 2}$ & $\mathbf{1 2}$ \\
Moraceace & $\mathbf{1 2}$ & $\mathbf{8}$ & $\mathbf{4}$ \\
Myraceae & $\mathbf{4}$ & - & $\mathbf{4}$ \\
Rubiaceae & $\mathbf{8}$ & $\mathbf{8}$ & - \\
Sapindaceae & $\mathbf{2}$ & $\mathbf{1}$ & $\mathbf{1}$ \\
Sterculeceae & $\mathbf{1}$ & $\mathbf{1}$ & \\
\hline
\end{tabular}

Tree species Distribution and Diversity of study sites: Table 2a show Polyalthia longifolia had the highest frequency of 30 among the identified tree species while Peltophorum pterocarpium had 24. Terminalia superba had frequency of 9 while the threatened Triplochiton scleroxylon was encountered 12 times. Total DBH ranged from $17.8 \mathrm{~cm}-188.9 \mathrm{~cm}$ while the total height of the trees enumerated ranged from $181.1 \mathrm{~cm}^{2}-6.7 \mathrm{~cm}^{2}$. The basal area range from $0.02 \mathrm{~cm}^{2}$ $-17.07 \mathrm{~cm}^{2}$. Total volume ranged from $0.51-52.86 \mathrm{~m}^{3}$. Cola gigantea had the highest mean dbh while Roystonea regia recorded the least dbh. Shorea roxburghii had the highest mean height of $181.1 \mathrm{~cm}$ while Ficus exasperate had the least mean height value of $6.7 \mathrm{~cm}$. (Table 3a). Table $2 \mathrm{~b}$ show Albizia ferruginea had the highest frequency of 5 among the identified tree species with Eucalyptus camaldulensis, Spondia mombian and Talbabua rosia having frequency of 4 respectively. Total dbh ranged from $37.7 \mathrm{~cm}-729.1 \mathrm{~cm}$ while total height ranges from $71.2 \mathrm{~cm}-4.5 \mathrm{~cm}$. Basal area ranges from $0.01-1.1 \mathrm{~m}^{2}$. Total volume is from $0.06-21.98 \mathrm{~m}^{3}$. Basal area ranged from 0.95 to $0.01 \mathrm{~m}^{2}$ with Milicia excelsa having the least value while the highest was number of $12.00 \mathrm{~m}^{2}$ in Terminalia cattapa, Terminalia superba; Talbabua rosia Eucalyptus camaldulensis had the highest mean height value. Milicia excelsa had the highest mean dbh of $345 \mathrm{~cm}$ while Millettia griffoniana recorded the least $\mathrm{dbh}$ of $28.6 \mathrm{~cm}$. Talbabua rosia had the highest mean height of $17.80 \mathrm{~cm}$ while Millettia griffoniana had the least mean height value of 4.5.cm. (Table $3 \mathrm{~b}$ ).

Species diversity indices for the study sites: Biodiversity indices are computed to show the level of diversity and abundance of species in different locations. Shannon's diversity typical values are generally between 1.5 and 3.5 in most ecological studies and the index is rarely greater than 4(Magurran,2004). It measures species abundance and richness so as to quantify the diversity of woody species (Magurran, 2004). The value of the Shannon's maximum diversity ( $\left.\mathrm{H}^{\prime}\right)$ obtained for CRIN is 2.36 . This implies that the species diversity of the area is moderate. This implies that diversity index in CRIN is moderate as revealed by the H' value (Table $4 a$ ). The Shannon diversity value for IITA is 3.04. It indicates that the species diversity in IITA is very high which is close to the upper limit value of 3.5 (Table 4). This corroborates the findings of Oladoye (2012). The high diversity of plant in IITA could be attributed to favorable climatic condition of high annual rainfall amount received in the area just like in most Southern part of Nigeria (Ayodele and Lameed, 1999) and protection over many years of good management. Species diversity indices affect the dominance and evenness. Therefore, as the richness increases, evenness is also affected.

Table 2a: Species and family of trees encountered in CRIN

\begin{tabular}{lll}
\hline Plant Species & Family & Number \\
\hline Milicia excels & Moraecea & 2 \\
Triplochiton scleroxylon & Malvaceae & 8 \\
Cola gigantean & Malvacea & 2 \\
Cola nitida & Sterculeacea & 1 \\
Delonix regia & Fabaceae & 12 \\
Terminalia superb & Combretaceae & 12 \\
Sterculia tragachanta & & 2 \\
Peltophorum plerocarpium & Fabaceae & 23 \\
Hildegardia barteri & Malvaceae & 2 \\
Roystonea regia & Arecaceae & 3 \\
Ficus thonningii & Moraeceae & 3 \\
Newbouldia laevis & Bignoniaceae & 1 \\
Shorea roxburghii & Dipterocarpaceae & 2 \\
Anacadium occidentail & Anarcadeacea & 1 \\
Polylthia longifolia & Annonaceacea & 29 \\
Blighia sapida & Sapindaceae & 1 \\
Terminalia randii & Rubiaceae & 7 \\
Ficus exasperate & Moraecea & 3 \\
Albizia zygia & Fabaceae & 1 \\
Acacia ferdherbia & Fabaceae & 1 \\
Morinda lucida & Rubiaceae & 1 \\
\hline
\end{tabular}

Table 2b: Species and family of trees encountered in IITA

\begin{tabular}{lll}
\hline Plant Species & Family & Number \\
\hline Cola gigantean & Malvaceae & 3 \\
Blighia sapida & Sapindacea & 1 \\
Albizia adantifolia & Fabaceae & 4 \\
Pterocarpus spp & Fabaceae & 1 \\
Albizia zygia & Fabaceae & 1 \\
Spondia monbin & Anacardiacea & 5 \\
Erythrophleum suaveolens & Fabaceae & 3 \\
Millettia griffoniana & Fabaceae & 1 \\
Triplochton scleroxylon & Malvaceae & 1 \\
Anthrocephalus cadmba & Fabaceae & 1 \\
Anogeissus leiocarpum & Combertaceae & 2 \\
Acacia spp & Fabaceae & 2 \\
Termilinia superb & Combertaceae & 2 \\
Ceiba pentandra & Malvaceae & 4 \\
Coco nucifera & Arecaceae & 2 \\
Hildegardia barteri & Malvaceae & 2 \\
Milicia excelsa & Moraceae & 1 \\
Terculia Africana & Moraceae & 3 \\
Eucalyptus camadulence & Myraceae & 4 \\
Termiliana cattapa & Combretaceae & 2 \\
Albizia lebbeck & Fabaceae & 1 \\
Cacia fistulia & Fabaceae & 2 \\
Talbabua rosia & Fabaceae & 4 \\
Delonix regia & Fabaceae & 1 \\
\hline & &
\end{tabular}


Table 3a: Tree species Distribution and Diversity in CRIN

\begin{tabular}{llllllllll}
\hline & & Total & Mean & Total & Mean & Total & Mean & Total & $\begin{array}{l}\text { Mean } \\
\text { Vol }\end{array}$ \\
\hline Species & Frequency & DBH(cm) & DBH & Height $(\mathrm{cm})$ & Height & B.A. & B.A & Vol & Vol \\
Albizia zygia & 1 & 97.1 & 97.1 & 14.5 & 14.5 & 0.08 & 0.08 & 1.09 & 1.09 \\
Anacardium occidentale & 1 & 146 & 146 & 17.8 & 17.8 & 0.17 & 0.17 & 3.02 & 3.02 \\
Blighia sapida & 1 & 160.9 & 160.9 & 11.6 & 11.6 & 0.21 & 0.21 & 2.39 & 2.39 \\
Cola gigantean & 3 & 156.7 & 156.7 & 17.5 & 17.5 & 0.20 & 0.20 & 3.42 & 3.42 \\
Cola nitida & 2 & 566.7 & 188.9 & 62.2 & 20.74 & 0.85 & 0.28 & 17.86 & 5.95 \\
Delonix regia & 203.1 & 101.55 & 26.9 & 13.45 & 0.20 & 0.10 & 3.52 & 1.76 \\
Ficus exasperate & 1 & 720.5 & 120.09 & 86.9 & 14.44 & 0.80 & 0.13 & 11.99 & 2.00 \\
ficus exasperate & 1 & 17.8 & 17.8 & 23.1 & 23.1 & 0.00 & 0.00 & 0.06 & 0.06 \\
Ficus thonningii & 2 & 55.1 & 55.1 & 6.7 & 6.7 & 0.02 & 0.02 & 0.16 & 0.16 \\
Hildegardia barteri & 1 & 196.5 & 98.25 & 33.6 & 16.8 & 0.15 & 0.08 & 2.58 & 1.29 \\
Milicia excelsa & 1 & 142.3 & 142.3 & 8.1 & 8.1 & 0.16 & 0.16 & 1.31 & 1.31 \\
Morinda lucida & 1 & 105.1 & 205.1 & 22.1 & 22.1 & 0.33 & 0.33 & 7.40 & 7.40 \\
Newbouldia laevis & 1 & 101.8 & 101.8 & 13.5 & 13.5 & 0.08 & 0.08 & 1.11 & 1.11 \\
Peltophorum pterocarpium & 24 & 32.6 & 72.6 & 11.1 & 11.1 & 0.04 & 0.04 & 0.47 & 0.47 \\
Polyalthia longifolia & 30 & 1593.5 & 149.73 & 254.5 & 10.60 & 4.84 & 0.20 & 52.86 & 2.20 \\
Roystonea regia & 1 & 165.5 & 51.88 & 294.9 & 9.83 & 0.80 & 0.03 & 9.96 & 0.33 \\
Shorea roxburghii & 1 & 165.5 & 16.5 & 16.5 & 0.22 & 0.22 & 3.60 & 3.60 \\
Sterculia setigera & 1 & 184.4 & 179.4 & 181.1 & 181.1 & 0.26 & 0.26 & 46.38 & 46.38 \\
Sterculia tragacantha & 1 & 76.5 & 76.5 & 20.5 & 20.5 & 0.27 & 0.27 & 5.56 & 5.56 \\
Terminalia randii & 11 & 1173.1 & 106.65 & 18.9 & 10.9 & 0.05 & 0.05 & 0.51 & 0.51 \\
Terminalia superb & 1 & 126.1 & 126.1 & 10.1 & 16.84 & 1.73 & 0.16 & 42.69 & 3.88 \\
Terminalia superb & 9 & 1530.7 & 170.09 & 128.4 & 10.1 & 0.13 & 0.13 & 1.28 & 1.28 \\
Triplochiton scleroxylon & 12 & 1743.5 & 145.29 & 244.8 & 20.4 & 2.66 & 0.30 & 39.82 & 4.42 \\
TOTAL & 114 & 13171.34 & 115.54 & 1702.5 & 14.94 & 17.07 & 0.24 & 68.27 & 5.69 \\
\hline & & & & & & & 327.29 & 2.87 \\
\hline
\end{tabular}

Table 3b Tree Species Distribution and Diversity in IITA

\begin{tabular}{|c|c|c|c|c|c|c|c|c|c|}
\hline IITA Species & Frequency & $\begin{array}{l}\text { Total } \\
\text { DBH(cm) }\end{array}$ & $\begin{array}{l}\text { Mean } \\
\text { DBH }\end{array}$ & $\begin{array}{l}\text { Total } \\
\text { Height }(\mathbf{c m})\end{array}$ & $\begin{array}{l}\text { Mean } \\
\text { Height }\end{array}$ & $\begin{array}{l}\text { Total } \\
\text { B.A. }\end{array}$ & $\begin{array}{l}\text { Mean } \\
\text { B.A }\end{array}$ & $\begin{array}{l}\text { Total } \\
\text { Vol }\end{array}$ & $\begin{array}{l}\text { Mean } \\
\text { Vol }\end{array}$ \\
\hline Acacia spp & 2 & 104.4 & 52.20 & 17.95 & 8.98 & 0.04 & 0.02 & 0.40 & 0.20 \\
\hline Albizia ferruginea & 5 & 217.5 & 43.50 & 31.3 & 6.26 & 0.09 & 0.02 & 0.59 & 0.12 \\
\hline Albizia lebbeck & 1 & 106.8 & 106.80 & 13.3 & 13.30 & 0.09 & 0.09 & 1.21 & 1.21 \\
\hline ALbizia zygia & 1 & 37.7 & 37.70 & 5.2 & 5.20 & 0.01 & 0.01 & 0.06 & 0.06 \\
\hline Anogeissus leiocarpus & 2 & 176.1 & 88.05 & 22.8 & 11.40 & 0.12 & 0.06 & 1.41 & 0.70 \\
\hline Anthrocephalus cadamba & 1 & 59.3 & 59.30 & 10.1 & 10.10 & 0.03 & 0.03 & 0.28 & 0.28 \\
\hline Blighia sapida & 1 & 35.5 & 35.50 & 5.5 & 5.50 & 0.01 & 0.01 & 0.06 & 0.06 \\
\hline Cacia fistula & 2 & 249.1 & 124.55 & 31.9 & 15.95 & 0.25 & 0.12 & 3.97 & 1.98 \\
\hline Ceiba pentandra & 3 & 187.9 & 62.63 & 24 & 8.00 & 0.12 & 0.04 & 0.99 & 0.33 \\
\hline Cici nucifera & 2 & 161.3 & 80.65 & 25.9 & 12.95 & 0.10 & 0.05 & 1.34 & 0.67 \\
\hline Cola gigantean & 3 & 134 & 44.67 & 21.2 & 7.07 & 0.06 & 0.02 & 0.46 & 0.15 \\
\hline Delonix regia & 1 & 356 & 356.00 & 21.8 & 21.80 & 1.01 & 1.01 & 21.98 & 21.98 \\
\hline Erythrophleum suaveolens & 3 & 235 & 78.33 & 33.1 & 11.03 & 0.16 & 0.05 & 1.82 & 0.61 \\
\hline Eucalyptus camaldulensis & 4 & 491.1 & 122.78 & 65.3 & 16.33 & 0.54 & 0.13 & 9.38 & 2.34 \\
\hline Hildegardia barteri & 2 & 93.9 & 46.95 & 10 & 5.00 & 0.04 & 0.02 & 0.18 & 0.09 \\
\hline Milicia execelsa & 1 & 345 & 345.00 & 4.9 & 4.90 & 0.95 & 0.95 & 4.64 & 4.64 \\
\hline Millettia griffoniana & 1 & 28.6 & 28.60 & 4.5 & 4.50 & 0.01 & 0.01 & 0.03 & 0.03 \\
\hline Pterocarpus spp & 1 & 107.5 & 107.50 & 8.1 & 8.10 & 0.09 & 0.09 & 0.74 & 0.74 \\
\hline Spondia mombian & 4 & 225.5 & 56.38 & 29.5 & 7.38 & 0.12 & 0.03 & 1.04 & 0.26 \\
\hline Talbabua rosia & 4 & 729.1 & 182.28 & 71.2 & 17.80 & 1.12 & 0.28 & 20.63 & 5.16 \\
\hline Terminal superb & 2 & 127.9 & 63.95 & 18.7 & 9.35 & 0.07 & 0.03 & 0.62 & 0.31 \\
\hline Terminalia cattapa & 2 & 230.1 & 115.05 & 24 & 12.00 & 0.23 & 0.11 & 3.01 & 1.50 \\
\hline Treculia Africana & 3 & 94.1 & 31.37 & 19.7 & 6.57 & 0.03 & 0.01 & 0.18 & 0.06 \\
\hline Triplochiton scleroxylon & 1 & 61.8 & 61.80 & 11.6 & 11.60 & 0.03 & 0.03 & 0.35 & 0.35 \\
\hline TOTAL & 52 & 4595.2 & 88.37 & 531.55 & 10.22 & 5.29 & 0.10 & 75.35 & 1.45 \\
\hline
\end{tabular}

The species dominance value of 0.15 and 0.05 respectively indicates a low dominance of any particular species in the two study sites. This means that no particular species dominates the area. Evenness index values usually ranges from 0 to 1 . It is equal to 1 when all the species have the same abundance and tends to zero when the near total flora is mainly consisted of a species. The evenness index calculated for both sites differs. The evenness value for IITA was 0.87 while that of CRIN was 0.44 .

The value from IITA tends towards 1 than that from CRIN. This implies that almost all the species encountered in IITA are almost equally represented as reflected in recurrent frequency of 1 and 2 (table $1 \mathrm{~b}$ ). This is not so in CRIN where a species is having a 
frequency of 30 and thus, the low evenness value tending more towards zero.

\begin{tabular}{cc} 
Table 4a: Species diversity indices for CRIN \\
\cline { 2 - 2 } Indices & Values \\
\hline CRIN & \\
Individuals & 114 \\
Dominance & 0.15 \\
Shannon & 2.36 \\
Evenness & 0.44 \\
Equitability & 0.74 \\
\hline
\end{tabular}

\begin{tabular}{ll} 
Table 4b: Species Diversity Indices IITA \\
\hline Indices & Values \\
\hline IITA & \\
Individuals & 52 \\
Dominance & 0.05 \\
Shannon & 3.04 \\
Evenness & 0.87 \\
Equitability & 0.96 \\
\hline
\end{tabular}

Comparison of ecological Analysis of the study sites: A total number of 166 individual trees were enumerated in the two study sites; 114 individuals in CRIN and 52 individuals in IITA. The 52 individuals in IITA belonged to 24 species and are of varied families (8) compared to CRIN and where 114 individuals belonged to only 20 species of just 12 families. This finding contradicts the findings of Oladoye (2012) who reported that the species richness depends on the number of species per units' area. The 52 individuals enumerated in IITA belonged to different species indicating a high abundance of diverse species. The 114 individuals enumerated in CRIN belonged to 20 species only. This implies that diversity in the individual trees was low and many of the trees were of the same species. The high species richness of IITA could be due to geological location and most importantly protection over a long period of time as one of the limitations in working in IITA was the constrain of not being allowed to cross lawn and having access to their protected trees.

Conclusion: This study yields a list of tree species used in beautification and ameliorating harsh weather condition along the streets and walk ways. Thus, revealing good and efficient management of tree resource within the institutes and subsequently, helped in tree biodiversity conservation. The continuous involvement of individuals, institutions, private organizations and non-governmental organization should be adequately rewarded to encourage them to do more in terms of tree planting in and around their buildings and the city.

\section{REFERENCES}

Adekunle, VA.; Adewole, OO; Akindele SO (2013b).

Tree species diversity and structure of a Nigerian
Strict Nature Reserve. Intl Soc for Trop. Ecol, 54(3):275-289.

Adeyemi, AA; Adesoye, PO (2016). Tree Slenderness Co-efficient and percent canopy cover in Oban Group forest, Nigeria. J. of Nat Sci. Res 6 (4): 917

Aidar, MPM; Godoy, JRL; Bergmann, J; Joly, CA (2001). Atlantic forest succession over calcareous soil, Parque Estadaul Turisitico do Alto Ribeira PETAR, SP. Rev. Bras. De Bot. 24:455-469

Ajewole, DO; Iyanda, S (2010). Effect of climate on cocoa yield: A case of Cocoa Research Institute (CRIN) farm, Oluyole Local Government, Oyo. $J$. of sust. Dev. in Afr, 12(1):350-358

Ayodele, IA; Lameed, GA (1999). Essentials of Biodiversity. Power house press and Publishers. Ibadan. Pp1-17

Babalola, FD; Raji, IA (2016). Perception of urban trees at main campus of University of Ilorin, Ilorin, Kwara state, Nigeria. App. Trop. Agric, 21 (1): 6067

Browne, S (2001). An evaluation of existing terrain elevation data formats with regards to inclusion in the charismatic terrain Editor. Internal Charismatic working paper, University of East Anglia.

Busing, RT; White, PS (1997). Species diversity and small scale disturbance in an old grown temperate forest: a consideration of gap portioning concepts. Oikos, 78:562-568

Burnham, RJ; Johnson, KR (2004). South America Paleaobotany and the origins of neotropical rainforests, Philos. trans of the royal soc, 359(1450):1595-1610

Gaston, JK (2000). Global patterns in biodiversity. Nature, 405, 220-227

Gentry, AH. (1990). Floristic similarities and differences between southern Central America and Upper and Central Amazonia. In: Gentry, A. H. (ed.), four neo tropical rainforests. Yale University Press, New Haven, USA. pp. 141-157. Global change Bio, 13: 913-921.

Hush, B; Beers, TW; Kershaw, JA (2003). Forest Mensuration. Wiley, New York 
Kent, M; Coker, P (1992). Vegetation description and analysis: A practical approach CRC press, Belhaven, London.

Magurran, AE (2004). Measuring Biological diversity. Blackwell Publishing, Oxford.

Margalef, DR (1972). Homage to Evelyn Hutchinson, or why is there an upper limit to diversity. Trans Connecticut Academy of Arts and Sci, 44: 211-235

McPherson, EG; Simpson, JR (1999). Carbon dioxide reduction through urban forestry: Guidelines for professional and volunteer tree planters. Gen. Tech. Rep. PSW

MEA (2005). Ecosystem and Human Well- being: Synthesis. Washington. D.C. Island press.

Nowak, DJ; Dwyer, JF (2007). Understanding the Benefits and Costs of Urban Forest Ecosystems. In J. E. Kuser (Ed.), Urban and Community Forestry in the Northeast. (2nd Edition). Springer Netherlands, pp. 25-46

Oladoye, AO (2012). Assessment of dynamics of forest regeneration in a tropical rainforest ecosystem in South-Western Nigeria. (PhD) thesis submitted to the department of Forestry and wildlife Management, College of Environmental Resource, Federal University of Agriculture, Abeokuta, Ogun state, Nigeria.126-132 Pp (Unpublished)
Onyekwelu, JC; Mosandl, R; Stimm, B (2007).Tree species diversity and soil status of primary and degraded tropical rainforest ecosystems in SouthWestern Nigeria. J Tropical Forest Sci. 20(3):193204.

Pielou, EC (1975). Ecological diversity. Wiley-Inter science New York, p. 165.

Shannon, CE; Wiener, W (1963). The mathematical theory of communication. University of Illinois press, Urbana, Illinois, USA.

Simpson, EH (1949). Measurement of diversity. Nature, 163: 688-696

Tenkouano, AE; Baiyeri, KP (2007). Adoption pattern and yield stability of banana and plantain genotypes grown in contrasting Agro-ecological zones in Nigeria. African Crop Science Conference Proceeding, 8:377-384

Valladares, F; Niinemets, U (2008). Shade tolerance, a key plant feature of complex nature and Consequences. Annual Review of Ecology, Evol. Syst. 19(1):237-257

Whittaker, RH (1972). Evolution and measurements of species diversity. Taxon, 21: 213-251. 